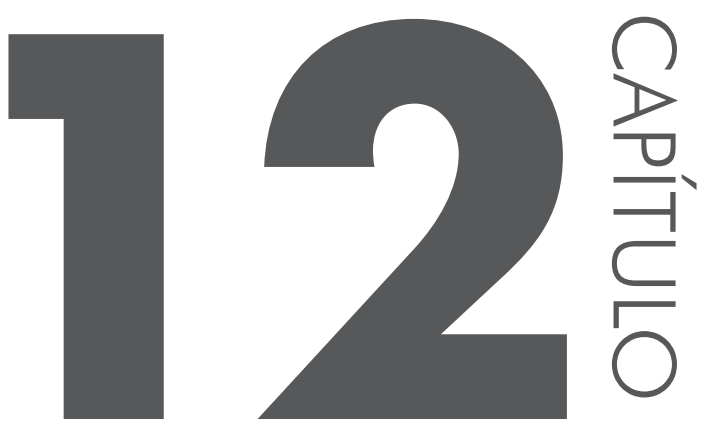

\title{
DIAGNÓSTICO DAS PROPRIEDADES E QUALIDADE DO LEITE PRODUZIDO POR AGRICULTORES FAMILIARES
}

Francine dos Santos Grosso Marly Sayuri Katsuda

\section{INTRODUC̣ÃO}

A qualidade do leite deve ser assegurada desde a sua obtenção até a sua transformação na indústria. A qualidade da matéria-prima é um fator primordial para conversão em derivados lácteos sob níveis seguros, por isso a legislação exige limites da contaminação inicial do leite, em que esse é influenciado diretamente pelo processo de obtenção na propriedade, condições de estocagem e transporte.

O Brasil caracteriza-se pela desvalorização no valor do leite in natura, falta de mão de obra especializada, baixa qualidade de alimentação animal, falta de 
informação e animais com baixo potencial produtivo, entre outros aspectos. Porém, a atividade leiteira é caracterizada pela mão de obra associada à agricultura, tornando-se, assim, essencial para a economia nacional. $\mathrm{O}$ país pode ser distinguido pelos contrastes existentes até nas cadeias produtivas de leite, nas quais existem propriedades que não possuem água nas dependências de ordenha ou energia elétrica para garantir a refrigeração adequada, até estabelecimentos rurais que possuem tecnologias das mais avançadas. Mesmo assim, a produção nacional elevou-se ao longo dos anos, com a ampliação do comércio com outros países e com o aumento da produtividade por animal (CORTEZ; CORTEZ, 2008).

O objetivo da melhoria na qualidade da matéria-prima não se resume à reparação de danos, mas se faz presente também no desejo de que as indústrias busquem produzir produtos com qualidade e segurança. A função dos processamentos tecnológicos visa à transformação de uma matéria-prima em um produto alimentício com características físico-químicas, microbiológicas e sensoriais adequadas e satisfatórias, proporcionando ao consumidor satisfação e segurança. Por esses motivos, o controle inicial da matéria-prima é fundamental (CORTEZ; CORTEZ, 2008).

Assim, este estudo teve o objetivo de avaliar o perfil da qualidade do leite proveniente de produtores da região norte do Paraná.

\section{LEITE}

A Instrução Normativa n. 62 (BRASIL, 2011) define leite como um produto oriundo da ordenha completa em condições de higiene, de vacas sadias, bem alimentadas e descansadas. Todavia, o leite de outros animais deve denominar-se segundo a espécie de que proceda.

O leite é um alimento de alto valor nutritivo; seu maior componente é a água, que representa mais de $87 \%$, na qual se encontram dissolvidos os demais componentes. Em solução, a lactose encontra-se em concentração, a qual compõe de $4,9 \%$ a $5,2 \%$. É o carboidrato majoritário no leite, responsável por seu sabor adocicado, e representa $50 \%$ dos sólidos desengordurados do leite. A lactose é o substrato responsável pelas transformações do leite para produtos fermentados, tais como queijos e iogurte, leite acidófilo, entre outros (TRONCO, 2008; WALSTRA; WOUTERS; GEURTS, 2006).

O segundo componente que compõe o teor de sólidos totais do leite é o lipídeo, totalizando entre 3,1\% e 4,0\% (FONSECA; SANTOS, 2000). A gordura é formada em sua maioria por triglicerídeos (97\% a 98\%), sendo que as pequenas quantidades pertencem aos esteróis, ácidos graxos livres e fosfolipídeos. Sua digestibilidade é elevada, e isso pode ser explicado pelo fato de sua membrana possuir enzimas catalíticas muito eficientes (TRONCO, 2008). 
As proteínas são os componentes coloidais mais importantes do leite e conferem sua cor característica, esbranquiçada e opaca. O teor médio de proteína do leite é de 3,2\%, e ela é subdividida em $80 \%$ de caseína e $20 \%$ de proteínas do soro. A caseína consiste em uma substância coloidal complexa que está associada com o cálcio e o fósforo, e é formada por várias submicelas que se mantém unidas por interações hidrofóbicas e pontes salinas. Já as proteínas do soro são formadas pelas frações: albumina do soro, $\alpha$-lactoalbumina, $\beta$-lactoglobulina, imunoglobulinas e protease-peptonas, que, em comparação com as caseínas, têm pequena influência sobre as propriedades físico-químicas. Ainda, em menor quantidade, contém vitaminas e minerais (WALSTRA, WOUTERS; GEURTS, 2006; TRONCO, 2008).

A composição do leite cru refrigerado é definida pela instrução normativa n. 62 do MAPA (Ministério da Agricultura, Pecuária e Abastecimento), a qual determina um limite mínimo de $3 \mathrm{~g} / 100 \mathrm{~g}$ para matéria gorda (lipídeos), de 8,4 g/100 g para ESD (extrato seco desengordurado) e de 2,9 g/100 g para proteína (BRASIL, 2011). Para Tronco (2008), os valores médios da composição química de um litro de leite de vaca são de 3,6\% de gordura, 9,1\% de ESD, composto por $3,3 \%$ de proteínas, $4,9 \%$ de lactose e $0,9 \%$ de minerais.

\subsection{Produção e consumo}

De acordo com dados estatísticos, de 1990 a 2009, a região Sudeste é a maior produtora de leite do país, seguida das regiões Sul e Centro-Oeste (MILKPOINT, 2013). O estado de Minas Gerais liderou a produção de leite em 2010, somando um volume de 8.388.039 litros, seguido de Rio Grande do Sul, com produção total de 3.633.834 litros, e Paraná, com 3.595.775 litros (EMBRAPA, 2013).

Segundo projeções feitas em 2010 pelo MAPA, a produção de leite deveria ter uma taxa de crescimento anual de 1,9\%, enquanto técnicos da Embrapa Gado de Leite estimavam um crescimento anual de 3 a 3,5\% para os anos seguintes, razões sustentadas pelo crescimento da produção de leite de $4 \%$ e da existência de programas de incentivo que podem ter produzido efeitos positivos sobre a produção e a produtividade, além das indústrias que auxiliam os produtores que melhoram a eficiência das propriedades, reduzindo o custo de matéria-prima (BRASIL, 2012).

É recomendável a ingestão diária de três porções de leite ou derivados, por serem ricos em proteínas e conterem cálcio. A média de consumo no Brasil é de 43,7 $\mathrm{kg}$ per capita (anual) e seu consumo está diretamente relacionado com a renda da população. Com isso, a média de consumo cai para 30,6 kg nas classes de menor renda, enquanto sobe para $63,6 \mathrm{~kg}$ para as de maior renda. Entre os produtos lácteos, o leite é o produto mais consumido, representando $88 \%$ e a maior incidência de consumo de leite está concentrado na região Sul (EMBRAPA, 2012). 
Essa representatividade deve-se pelo seu consumo na forma pasteurizada, UHT, esterilizado, ou mesmo leite fresco de vaca. Segundo levantamento da Embrapa (EMBRAPA, 2012), o consumo de leite para a família com renda de R $\$$ $1.245,00$ é de $28 \mathrm{~kg}$ per capita ao ano, enquanto o consumo aumenta para 52,6 $\mathrm{kg}$ na classe que possui renda de $\mathrm{R} \$ 4.150,00$. Quanto ao tipo de leite, a ingestão média de leite pasteurizado é de $25,6 \mathrm{~kg}$ per capita, enquanto o de leite de vaca fresco é de 9,8 kg per capita, sendo que a região Sul destaca-se pelo maior consumo de leite.

De acordo com o IBGE (Instituto Brasileiro de Geografia e Estatística) (INSTITUTO BRASILEIRO DE GEOGRAFIA E ESTATÍSTICA, 2012), a produção de leite no estado do Paraná no ano de 2011 foi de 3.815 .582 litros, totalizando um valor de produção de $\mathrm{R} \$ 2.862 .214,00$, o que resulta em um valor de R \$ ,75/litro. Na cidade de Castro, que era a primeira no ranking de produção no Paraná e no país, segundo o IBGE de 2010, a produção em 2011 foi de 210.000 litros, totalizando um valor de R 172.200 , resultando em $\mathrm{R} \$$ 0,82/litro. Em Londrina, a produção é modesta, resultando em 6.300 litros, totalizando um montante de $\mathrm{R} \$ 4.914,00$, o que resulta no valor de $\mathrm{R} \$ 0,78$ / litros. No município de Sertanópolis, a produção média de leite é de 750 litros, com o mesmo preço gerado na cidade de Londrina. Esses dados mostram que a região norte do Paraná ainda tem muito potencial para desenvolvimento em produção leiteira (INSTITUTO BRASILEIRO DE GEOGRAFIA E ESTATÍSTICA, 2012).

\subsection{Composição microbiológica do leite}

O leite possui um alto valor nutritivo que o torna adequado para o consumo humano e, consequentemente, proporciona o desenvolvimento de diversos microrganismos. É um alimento altamente perecível, e suas características podem ser facilmente alteradas por meio de manipulação, presença de células somáticas e ação de microrganismos. A mastite bovina é uma doença ocasionada por bactérias que acomete os tetos das vacas, ocasionado prejuízos na bovinocultura de leite (FONSECA; SANTOS, 2000; FAGAN et al., 2008).

A carga microbiana no leite cru é consequente das condições higiênicas durante o processo de ordenha. A contagem bacteriana baixa é resultante de uma ordenha higiênica adequada, seguida de resfriamento rápido e refrigeração na temperatura entre 4 e $7^{\circ} \mathrm{C}$, de acordo com a recomendação legal. $\mathrm{O}$ regulamento técnico de identidade e qualidade de leite cru refrigerado, na instrução normativa n. 62 do MAPA, define novas metas no requisito CBT (contagem bacteriana total) até 2016, ilustradas na Tabela 12.1 (BRASIL, 2011). 
Tabela 12.1 Metas na melhoria da contagem bacteriana total definidos na Instrução Normativa $n^{0} 62$ na região Sul (BRASIL, 2011)

\begin{tabular}{cc}
\hline Periodo & Limites (UFC/ml) \\
\hline Janeiro/2012 a junho/2014 & Máx. $6 \times 10^{5}$ \\
Julho/2014 a junho/2016 & Máx. $3 \times 10^{5}$ \\
A partir de julho/2016 & Máx. $1 \times 10^{5}$ \\
\hline
\end{tabular}

A contagem de células somáticas é composta por células de defesa ou epiteliais, tais como leucócitos. O aumento da contagem de células somáticas promove um desbalanceamento das frações proteicas e de sais, compromete a produtividade das vacas e a qualidade dos produtos lácteos (FONSECA; SANTOS, 2000). A legislação preconiza os limites de células somáticas em leite cru resfriado com prazos previstos, visando a alcançar contagens próximas às recomendadas consideradas seguras (BRASIL, 2011).

Tabela 12.2 Metas na melhoria da contagem de células somáticas definidas na instrução normativa n. 62, na região Sul (BRASIL, 2011)

\begin{tabular}{cc}
\hline Periodo & Limites (CS/ml) \\
\hline Janeiro/2012 a junho/2014 & Máx. $6 \times 10^{5}$ \\
Julho/2014 a junho/2016 & Máx. $5 \times 10^{5}$ \\
A partir de julho/2016 & Máx. $4 \times 10^{5}$ \\
\hline
\end{tabular}

Habitualmente, a glândula mamária contém um número reduzido de bactérias ao longo dos canais que conduzem o leite, contaminando-o quando é secretado. As bactérias presentes no úbere penetram possivelmente no canal do teto, e a sua multiplicação e o movimento físico as distribuem no leite. Os primeiros jatos apresentam, por isso, maior número de microrganismos. Porém, o ordenhador deve ter hábitos higiênicos, vestir-se com roupas asseadas, gozar de boa saúde e não ter ferimentos nas mãos que possam aportar agentes patogênicos (estreptococos e estafilococos). Os excrementos dos animais também são ricos em microrganismos diversos e constituem foco importante de enterobactérias, como Escherichia coli e outros (TRONCO, 2008).

\subsection{Fatores que afetam a composição do leite}

Existem vários fatores que afetam a composição química do leite. Eles são divididos em intrínsecos e extrínsecos. Os intrínsecos estão relacionados ao animal 
quanto à raça, a fatores fisiológicos, como a etapa colostral e a fase de lactação, e à saúde do animal. Já os extrínsecos se referem às condições ambientais e de coleta que dependem da alimentação, tipo de ordenha, condições do alojamento dos animais e, ainda, variações quanto à estação e ao clima (MAHIEU, 1991).

As raças leiteiras são mais apropriadas para a produção de leite, e, entre elas, as principais diferenças se dão pelos níveis de gordura e proteína, sendo que esses componentes são bases de pagamento e diferenciação para os produtores de leite (GONZÁLEZ; CAMPOS, 2003). A etapa colostral ocorre alguns dias antes e depois do parto, onde os tetos do animal secretam um material chamado de colostro. Esse material tem um alto valor proteico, principalmente no que diz respeito às imunoglobulinas. O colostro consiste em um líquido amarelo, viscoso e que resulta uma reação ácida; por esses motivos, são sensíveis às transformações industriais (MAHIEU, 1991).

A saúde do animal envolve uma higiene eficiente na ordenha, traumas e lesões nos tetos ocasionados pelo conjunto de ordenha ou outros materiais, as condições de alojamento e conforto e a retenção láctea ou qualquer tipo de estresse que ocasiona a diminuição da resistência natural dos tetos. Esses problemas levam a uma diminuição na taxa de proteínas e de triglicerídeos (MAHIEU, 1991).

A fase de lactação é importante porque influencia na composição do leite, e, à medida que ela avança, aumenta o conteúdo de gordura, proteína e lactose. A alimentação pode influenciar na composição do leite, pois essa depende da quantidade de nutrientes que chegam à glândula mamária por meio do sangue (SIMILI; LIMA,2007).

A ordenha mecanizada é a mais utilizada, e depende dela a extração máxima de leite de boa qualidade sem afetar a saúde do animal. Com isso, deve se dar mais atenção para a higiene desse material antes e após a ordenha, para evitar a instalação de microrganismos que encontram, na máquina, um excelente meio de cultivo. O tipo de alojamento, aberto, fechado ou semiaberto, bem como a redução do espaço e a altura, afetam a saúde do animal, consequentemente alterando a composição química do produto final. As variações quanto às estações do ano são as mais importantes, principalmente pelo nível de gordura. Essa influência se deve pela combinação da alimentação, fatores climáticos e fase de lactação da vaca (MAHIEU, 1991).

As concentrações de células somáticas e bactérias determinam a qualidade do leite, principalmente quando a matéria-prima é destinada para o processamento, portanto a qualidade do leite cru influi na estabilidade microbiana e físico-química no leite pasteurizado e em seus derivados (RUIZ-CORTÉS et al., 2012).

Baseado nesse contexto, o presente estudo teve a finalidade de avaliar as propriedades e a qualidade microbiológica e físico-química dos leites produzidos na região norte do Paraná 


\section{MATERIAIS E MÉTODOS}

O presente estudo contou com a colaboração da Empresa Paranaense de Assistência Técnica e Extensão Rural (Emater/PR), unidade de Londrina, acompanhando-nos nas visitas de 21 propriedades para coletar as amostras de leite e no levantamento das características das unidades produtoras com a finalidade de efetuar um breve diagnóstico das condições higiênicas e sanitárias. A avaliação da qualidade do leite consistiu na caracterização físico-química e microbiológica do mesmo com o apoio do laboratório APCBRH, em Curitiba.

\subsection{Diagnóstico das propriedades}

As propriedades produtoras de leite selecionadas foram realizadas na região sugerida pelo coordenador da produção leiteira da Emater, de acordo com os limites de CCS (contagem de células somáticas) e CBT (contagem bacteriana total) fora dos padrões legais no período de julho de 2011 a janeiro de 2013, na região norte do Paraná. Esses dados foram analisados no programa Microsoft Office Excel 2010, adotando o tratamento estatístico descritivo. As médias e seus desvios-padrão foram comparados aos limites exigidos pela instrução normativa n. 62 do MAPA, que regulamenta a qualidade do leite in natura.

\subsection{Avaliação das propriedades visitadas}

Após o levantamento das propriedades, foram realizadas visitas com o acompanhamento de um técnico da Emater/PR, nas quais foi efetuada uma avaliação da estrutura das propriedades em relação a:

- tipo de ordenha;

- tipo de resfriador;

- volume de produção diária;

- volume de leite resfriado;

- número de ordenhas.

Em seguida, foi realizada a amostragem no tanque de estocagem do leite em frascos estéreis. Antes da coleta, o leite foi homogeneizado no tanque de refrigeração e, logo em seguida, foram coletados aproximadamente $200 \mathrm{ml}$ de leite. As amostras foram codificadas e armazenadas em uma caixa isotérmica com gelo para manter a temperatura do leite.

Os frascos com a amostra foram acondicionados em caixas isotérmicas com gelo e transportados até a UTFPR (Universidade Tecnológica Federal do Paraná), campus Londrina. No laboratório de laticínios, as amostras foram acondiciona- 
das em frascos com agentes estabilizantes para análise microbiológica e CCS e enviados ao laboratório de análise APCBRH. Os laudos liberados pelo laboratório oficial foram tabulados e comparados ao padrão legal. Os dados obtidos foram comparados à qualidade previamente observada das mesmas propriedades e permitiu identificar as possíveis limitações na qualidade do leite.

\section{RESULTADOS E DISCUSSÃO}

Os resultados apresentados a seguir tratam da avaliação das amostras após as visitas realizadas nas propriedades. Esses dados são apresentados na forma de agrupamento por intervalos de CCS e CBT e as proporções de propriedades que se enquadraram em cada faixa avaliada. A partir desses valores, foi possível diagnosticar as propriedades que conseguiram atingir os padrões legais e as proporções que ainda precisam adequar suas instalações para atender aos limites exigidos pela instrução normativa n 62 do MAPA (BRASIL, 2011).

A Figura 12.1 apresenta a quantidade de propriedades produtoras de leite, em porcentagem, e suas respectivas médias quanto à contagem de bactérias totais. Dessas, $10 \%$ apresentaram níveis de CBT entre 3,0 e 6,0×10 $\mathrm{UFC} / \mathrm{ml}, 33 \%$ exibem valores acima de $9,0 \times 10^{5} \mathrm{UFC} / \mathrm{ml}$ e $57 \%$ entre 0 e $3,0 \times 10^{5} \mathrm{UFC} / \mathrm{ml}$.

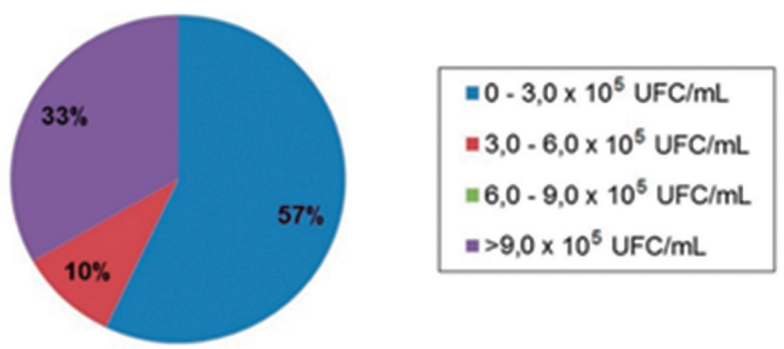

Figura 12.1 Proporções de propriedades produtoras de leite (\%) agrupadas em intervalos de CBT (contagem de bactérias totais)

Ribeiro Neto et al. (2012), menciona que leite cru refrigerado com valores de CBT superiores a $1,0 \times 10^{6} \mathrm{UFC} / \mathrm{ml}$ acusa problemas sérios com procedimentos higiênicos na obtenção do leite nas propriedades; geralmente pode ser falha na limpeza dos ordenhares e na linha do leite, bem como insuficiente refrigeração do leite.

A Figura 12.2 demonstra que $66,5 \%$ das propriedades estariam dentro dos limites exigidos pela legislação até 2014, porém, nos próximos anos, com o rigor dos padrões legais na contagem bacteriana, essas propriedades representarão apenas 19\% em 2016 na região Sul do país. 


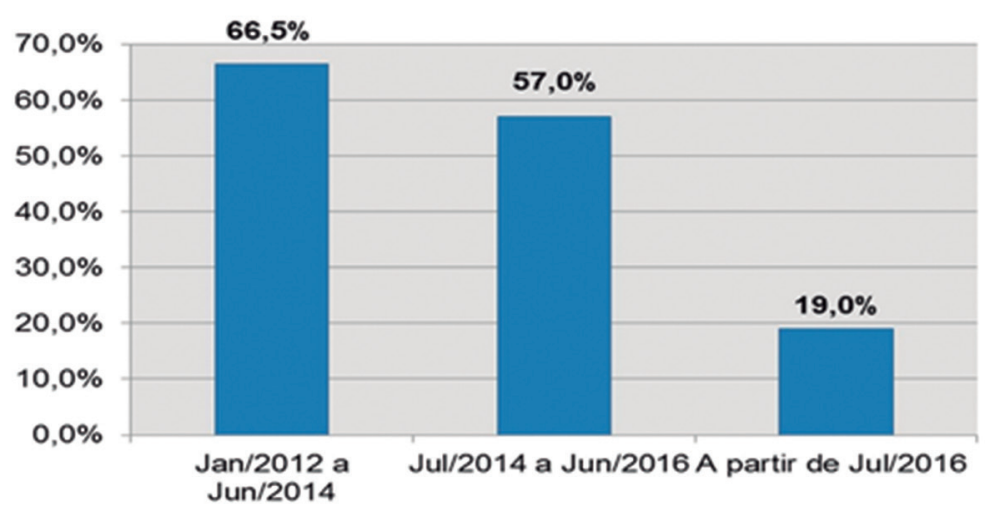

Figura 12.2 Estimativa da proporção de propriedades produtoras de leite que apresentaram as CBT dentro dos padrões legais exigidos pela instrução normativa n. 62 do MAPA, de 2014 a 2016 (BRASIL, 2011)

Bozo et al. (2013) mostraram, em seu estudo, que a implantação de boas práticas na obtenção do leite reduziu $93,4 \%$ de CBT no leite cru refrigerado nas propriedades assistidas no município de Pitangueiras, Paraná. Esse trabalho demonstrou que é possível enquadrar esse parâmetro nos padrões legais mudando apenas hábitos e implantando práticas higiênicas na produção do leite.

A Figura 12.3 ilustra a proporção de propriedades produtoras de leite, em porcentagem, e suas respectivas médias quanto à CCS. O resultado demonstrou que $5 \%$ das propriedades avaliadas apresentaram valores acima de $9,0 \times 10^{5} \mathrm{CS} /$ $\mathrm{ml}, 14 \%$ entre 6,0 e $9,0 \times 10^{5} \mathrm{CS} / \mathrm{ml}, 24 \%$ entre 0 e $3,0 \times 10^{5} \mathrm{CS} / \mathrm{ml}$ e $57 \%$ entre 3,0 e $6,0 \times 10^{5} \mathrm{CS} / \mathrm{ml}$.

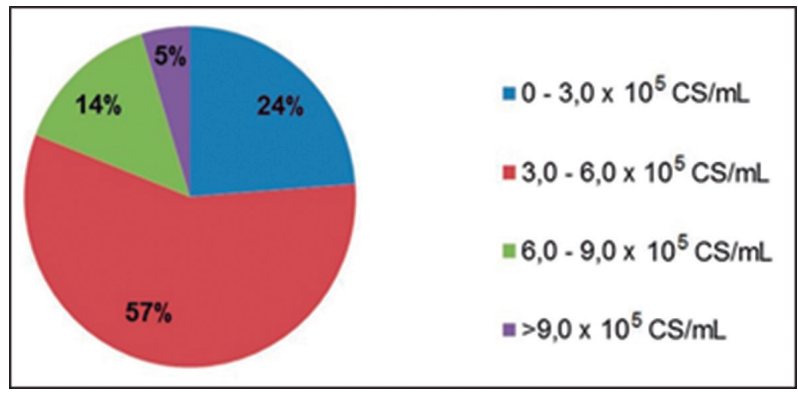

Figura 12.3 Proporções de propriedades produtoras de leite (\%) agrupados em intervalos de CCS

Silva et al. (2010) mencionam que, em vacas que apresentam valores de células somáticas superiores a $2,5 \times 10^{5} \mathrm{CS} / \mathrm{ml}$ de leite produzido podem ser diagnosticadas com mastite subclínica, o que pode afetar diretamente a produtividade do animal e a qualidade do leite. 
A Figura 12.4 demonstra que $81 \%$ das propriedades ainda se enquadram no padrão legal no ano de 2013 (BRASIL, 2011). Porém, em 2016 esse índice cairia para $52,5 \%$. Isso demonstra que ações corretivas precisam ser realizadas nas propriedades avaliadas para que possam produzir leite de qualidade adequada e garantir a sua atividade de renda.

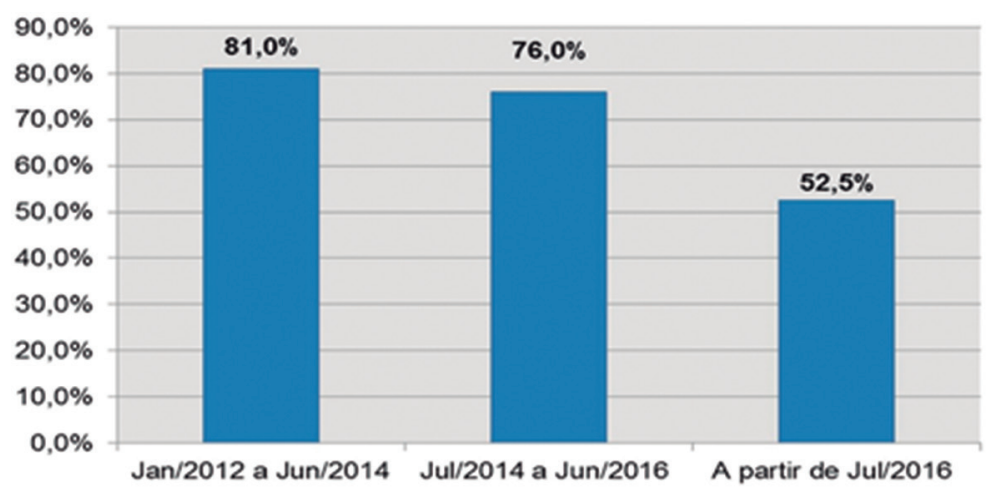

Figura 12.4 Estimativa da proporção de propriedades produtoras de leite que apresentaram a CCS das amostras de leite dentro dos padrões legais exigidos pela instrução normativa n. 62 do MAPA, de 2014 a 2016 (BRASIL, 2011)

De acordo com os dados obtidos por Bozo et al. (2013), implantar medidas corretivas no manejo das vacas leiteiras durante o processo da ordenha contribuiu com uma redução de 74,3\% nos níveis de CCS. Boas práticas higiênicas, que envolvem o diagnóstico prévio com o teste do caneco de fundo preto antes da ordenha, limpeza adequada dos tetos e aplicação do pré-dipping, e manter os animais em pé após a ordenha para promover o fechamento do esfíncter dos tetos das vacas colaboram com a saúde dos tetos, garantindo a produtividade dos animais (FONSECA; SANTOS, 2000).

A Figura 12.5 apresenta a proporção de propriedades que se enquadraram aos padrões legais quanto ao teor de gordura, proteínas e ESD.

Ao avaliar o teor de gordura das amostras de leite, $76 \%$ das propriedades avaliadas atenderam aos limites legais da legislação vigente. Por outro lado, todas as propriedades produzem leites com teores de proteínas e ESD dentro dos padrões legais.

Fonseca e Santos (2000) mencionam que vacas com infecções mastíticas clínicas produzem leite com baixo teor de gordura e lactose. Possivelmente, as amostras de leite que apresentaram baixo teor de gordura ao longo do período de estudo estão diretamente relacionadas ao elevado teor de CCS, classificados como leite proveniente de animais com mastite clínica. 


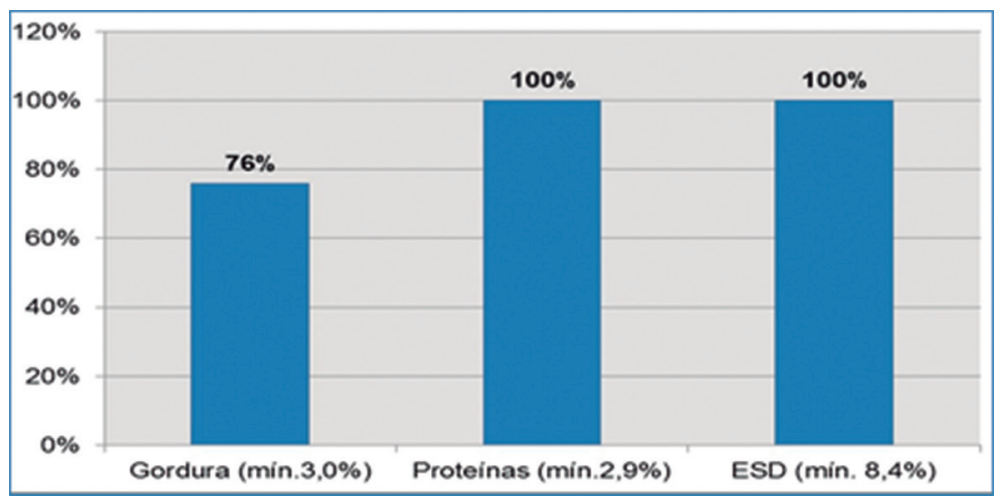

Figura 12.5 Proporção de propriedades que tiveram as amostras de leite com o teor de gordura, proteína e extrato seco desengordurado dentro dos padrões exigidos pela instrução normativa n. 62 do MAPA (BRASIL, 2011)

As seis propriedades visitadas realizavam a ordenha semimecanizada, ou seja, utilizavam ordenhadeira mecânica balde ao pé (Figura 12.6), representando $86 \%$ das propriedades entrevistadas.

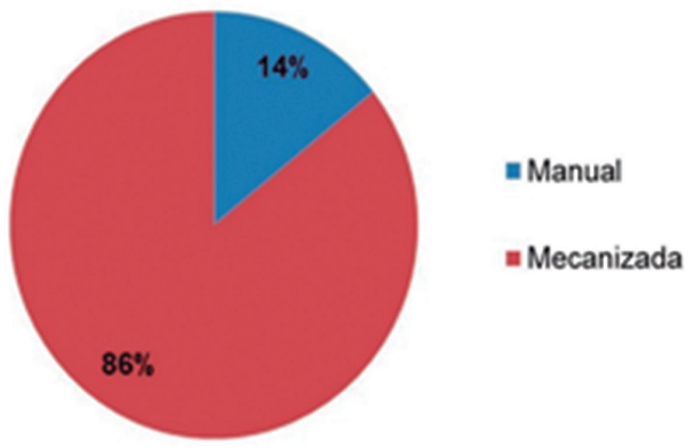

Figura 12.6 Tipo de ordenha utilizada nas propriedades produtoras de leite

Somente uma propriedade apresentou ordenha manual, pois não produzia volume suficiente para investir no sistema mecanizado, já que sua produção era inferior a 50 litros ao dia. De acordo com a legislação, o leite pasteurizado comercializado deve ser obtido no sistema de ordenha mecanizada.

De acordo com a pesquisa realizada por Carvalho et al. (2013) sobre a qualidade do leite cru refrigerado obtido por meio de ordenha manual e mecânica, foi observado que a quantidade de CCS encontrado no leite ordenhado manualmente $\left(4,6 \times 10^{5} \mathrm{CS} / \mathrm{ml}\right)$ diferiu significativamente do leite ordenhado mecanicamente $\left(10 \times 10^{5} \mathrm{CS} / \mathrm{ml}\right)$, sendo que o leite com valores acima de $6,0 \times 10^{5} \mathrm{CS} / \mathrm{ml}$ não poderiam ser comercializados. Isso mostra que a higiene não depende da tecnologia aplicada, mas sim dos cuidados que o ordenhador empenha na obtenção do leite. 
As mesmas propriedades que coletavam o leite no sistema mecanizado possuíam resfriador em tanque de expansão (Figura 12.7).

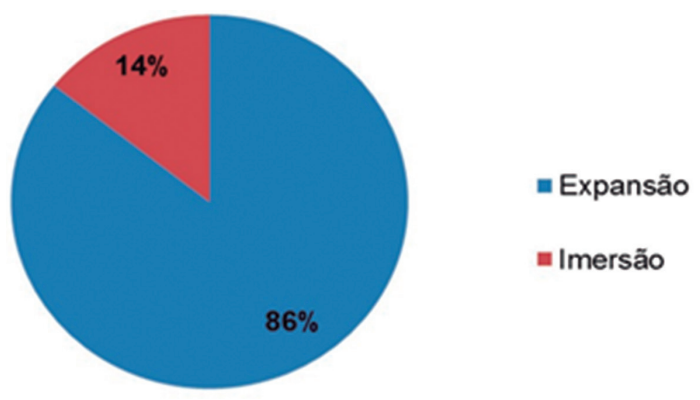

Figura 12.7 Tipo de resfriador utilizado nas propriedades produtoras de leite

A propriedade que retirava o leite manualmente utilizava o sistema de resfriamento por imersão. Embora não exista exigência legal sobre o uso somente do resfriador em tanques de expansão, o sistema de imersão exige atenção maior do produtor, pois, como o resfriamento ocorre na forma estática, o leite pode não resfriar dentro do período recomendado pela legislação, que é de três horas, exigindo uma agitação manual temporária para que o leite não sofra grandes alterações microbianas durante a estocagem, até resfriá-lo a temperatura de $4{ }^{\circ} \mathrm{C}$, conforme o regulamento para leite cru (BRASIL, 2011).

A Figura 12.8 apresenta a capacidade dos resfriadores utilizados pelos produtores de leite. Nas visitas nas propriedades que utilizam o resfriador por expansão térmica, constatou-se que $29 \%$ possuem esse equipamento com capacidade de 0 a 1.000 litros, e $57 \%$, com capacidade superior a 1.000 litros.

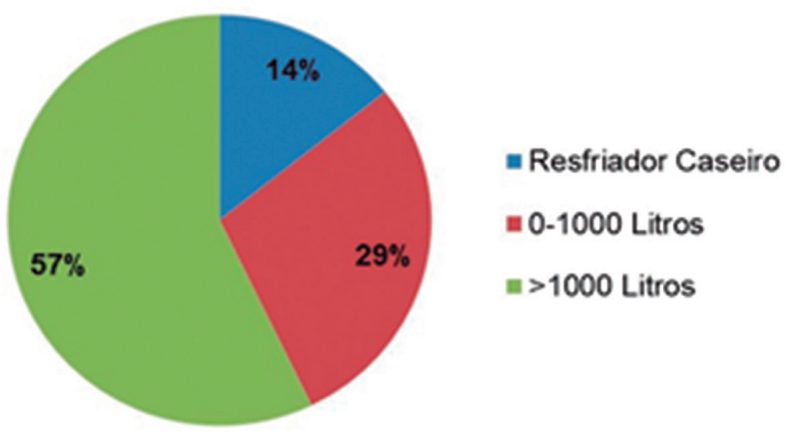

Figura 12.8 Capacidade em litros dos resfriadores das propriedades produtoras de leite

Pode-se supor que os produtores visam a ampliar seu investimento, pois parte desses tanques de expansão receberam apoio financeiro do próprio laticínio, visando a aumentar a produtividade na propriedade. 
A Figura 12.9 ilustra o volume de produção diária das propriedades produtoras de leite: $28 \%$ das propriedades produz entre 0 e 150 litros diários; $29 \%$ produzem de 150 a 300 litros por dia; e os demais produzem mais do que 300 litros diários.

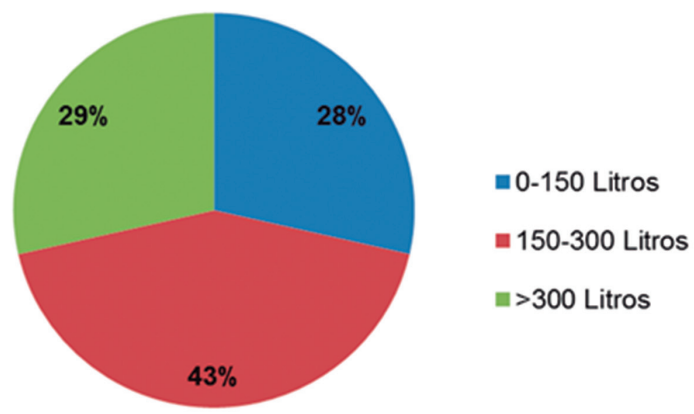

Figura 12.9 Volume de produção diária das propriedades produtoras de leite

Isso demonstra que a maioria dos produtores está investindo na atividade leiteira, e que foram levantadas as necessidades de assistência envolvendo boas práticas na produção, alimentação animal e investimento na estrutura nas salas de ordenha.

A Figura 12.10 exibe a quantidade de ordenhas que são realizadas por dia nas propriedades produtoras de leite. Dessas, $86 \%$ realizam uma ordenha ao dia, e $14 \%$ realizam duas ordenhas por dia. A maioria das propriedades executa uma ordenha diária, pois geralmente o proprietário e a esposa participam diretamente da atividade leiteira, não tendo recurso disponível para contratar mão de obra para auxiliar na ampliação da produção leiteira.

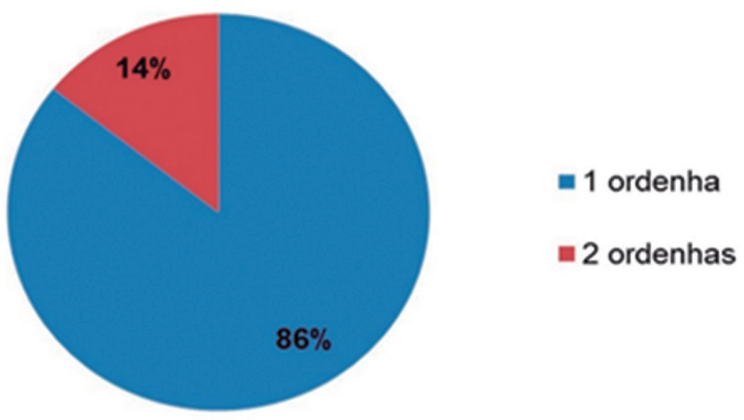

Figura 12.10 Quantidade de ordenhas realizadas por dia nas propriedades produtoras de leite visitadas

A Figura 12.11 apresenta a quantidade de vacas em estágio de lactação. As propriedades que possuem de 1 a 15 vacas nessas condições somam $28 \%$; já as que possuem de 15 a 30 animais resultam em $29 \%$; de 30 a 45 vacas correspon- 
dem a $14 \%$ das propriedades; e aquelas propriedades que possuem mais de 45 animais nessas condições somam $29 \%$.

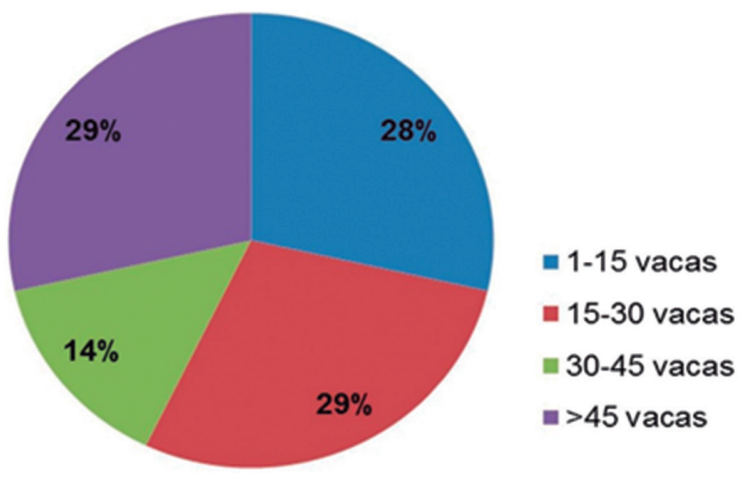

Figura 12.11 Quantidade de vacas em estágio de lactação nas propriedades produtoras de leite visitadas

As propriedades que possuem de 1 a 15 vacas apresentou um volume diário de produção inferior a 50 litros; as que possuem de 15 a 30 animais produzem um volume de 200 a 350 litros por dia; e as que possuem mais de 45 animais têm uma produção diária superior a 300 litros. Ao contrário da tendência observada nas demais classes, a propriedade que possuía de 30 a 45 animais produzia um volume diário de 150 litros. Possivelmente, essa propriedade apresentava problemas com manejo sanitário dos animais, tais como mastite clínica.

\section{CONCLUSÃO}

A maioria das propriedades avaliadas (65\%) apresentou CBT dentro dos limites estabelecidos pela legislação vigente para o período de até 2014 , e $81 \%$ das propriedades estariam nessa mesma faixa para os limites de CCS. Ao avaliar o teor de proteínas e ESD, as amostras de leite demonstraram que todas as propriedades estão de acordo com os limites estabelecidos pela legislação, porém, 24\% das propriedades apresentaram o teor de gordura inferior aos limites.

Nas propriedades visitadas, observou-se que $86 \%$ delas utilizam ordenha mecanizada e resfriadores em tanque de expansão térmica, das quais $57 \%$ possuem capacidade superior a 1.000 litros. Somente $29 \%$ das propriedades têm um volume de produção diária maior que 300 litros diários; cerca de 90\% das propriedades executam uma ordenha ao dia; e $43 \%$ das propriedades possuem mais de 30 animais em estágio de lactação.

A partir desse diagnóstico, foi possível observar que as propriedades produtoras possuem um potencial para elevar sua produtividade, por meio de ações como boas práticas na produção leiteira e a adequação na estrutura nas salas de 
ordenha. Foi proposta uma ação posterior para avaliar as condições de obtenção do leite por meio de visitas in loco e aplicação de um check-list, porém, somente duas propriedades se manifestaram interessadas nessa atividade.

\section{REFERÊNCIAS}

BOZO, G. A. et al. Adequação da contagem de células somáticas e da contagem bacteriana total em leite cru refrigerado aos parâmetros da legislação. Arquivo Brasileiro de Medicina Veterinária e Zootecnia, v. 65, n. 2, p. 589-594, 2013.

BRASIL. Ministério da Agricultura, Pecuária e Abastecimento. Instrução Normativa n. 62, de 29 de dezembro de 2011. Regulamento Técnico de Produção, Identidade e Qualidade do Leite tipo A, Leite Cru Refrigerado, Leite Pasteurizado e Coleta de Leite Cru Refrigerado e seu Transporte a Granel. Disponível em: <http://www.sindilat.com.br/ gomanager/arquivos/IN62_2011(2).pdf>. Acesso em: 8 dez. 2012.

. Ministério da Agricultura, Pecuária e Abastecimento. ACS, 2012. Projeções do Agronegócio: Brasil 2011/2012 a 2021/2022. Ministério da Agricultura, Pecuária e Abastecimento. Assessoria de Gestão Estratégica. Disponível em: <http://www. agricultura.gov.br/arq_editor/file/Ministerio/gestao/projecao/PROJECOES-web.pdf>. Acesso em: 19 fev. 2013.

CARVALHO, T. S. et al. Qualidade do leite cru refrigerado obtido através de ordenha manual e mecânica. Revista do Instituto de Laticínios “Cândido Tostes”, v. 68, n. 390, p. 5-11, 2013.

CORTEZ, M. A. S.; CORTEZ, N. M. S. Qualidade do leite: boas práticas agropecuárias e ordenha higiênica. Niterói: EdUFF, 2008.

EMBRAPA. Panorama do Leite. Ano 6, n. 65. Juíz de Fora: Embrapa Gado de Leite, 2012. . Ranking da Produção de Leite por Estado, 2010/2011. Disponível em: <http:// www.cnpgl.embrapa.br/nova/informacoes/estatisticas/producao/tabela0240.php>. Acesso em: 24 fev. 2013.

FAGAN, E. P. et al. Avaliação de padrões físico-químicos e microbiológicos do leite em diferentes fases de lactação nas estações do ano em granjas leiteiras no Estado do Paraná -Brasil. Semina Ciências Agrárias, Londrina, v. 29, n. 3, p. 651-660, jul./set., 2008. FONSECA, L. F. L.; SANTOS, M. V. Qualidade do leite e controle da mastite. São Paulo: Lemos Editorial, 2000.

GONZÁLEZ, F. H. D.; CAMPOS, R. Indicadores metabólico-nutricionais do leite. In: I Simpósio de Patologia Clínica Veterinária da Região Sul do Brasil. Anais. Porto Alegre: Gráfica da Universidade Federal do Rio Grande do Sul, p. 31-47, 2003. Disponível em: $<$ http://www.lume.ufrgs.br/bitstream/handle/10183/13176/000386500.pdf? sequence=1>. Acesso em: 21 ago. 2013.

INSTITUTO BRASILEIRO DE GEOGRAFIA E ESTATÍSTICA. Produção da Pecuária Municipal 2011. Rio de Janeiro: INSTITUTO BRASILEIRO DE GEOGRAFIA E ESTATÍSTICA, 2012. Disponível em: <http://www.ibge.gov.br/home/estatistica/ economia/ppm/2010/default.shtm> Acesso em: 3 ago. 2013. 
MAHIEU, H. Factores que influyen em lacomposición de la leche. In: LUQUET, F. M. Leche y produtos lacteos: vaca, oveja, cabra. v. 1. Zaragoza: Editorial Acribia, S.A. p. 117-180, 1991.

MILKPOINT. Estatísticas: produção brasileira de leite em milhões de litros - por unidades da Federação. Disponível em: <http:/www.milkpoint.com.br/estatisticas/ Producao_Estado.htm>. Acesso em: 24 fev. 2013.

RIBEIRO NETO, A. C. et al. Qualidade do leite cru refrigerado sob inspeção federal na região Nordeste. Arq. Bras. Med. Vet. Zootec., v. 64, n. 5, p. 1343-1351, 2012.

RUIZ-CORTÉS, T. et al. Factores que afectan el recuento de UFC em la leche em tanque em hatos lecheros del norte de Antioquia-Colombia. Revista U.D.C.A Actualidad \& Divulgación Científica, v. 15, n. 1, p. 147-155, 2012.

SILVA, M. A. P. et al. Qualidade do leite na indústria de laticínios. Revista do Instituto Adolfo Lutz, São Paulo, v. 69, n. 1, p. 23-28, 2010.

SIMILI, F. F.; LIMA, M. L. P. Como os alimentos podem afetar a composição do leite das vacas. Pesquisa \& Tecnologia, v. 4, n. 1, 2007.

TRONCO, V. M. Manual para Inspeção da Qualidade do Leite. 3. ed. Santa Maria: Editora UFSM, 2008.

WALSTRA, P.; WOUTERS, J. T. M.; GEURTS, T. J. Dairy science and technology. 2. ed. Boca Raton: CRC, 2006. 60 p. 